\title{
EFFICIENCY EFFECTS OF TAX DEDUCTIONS FOR WORK-RELATED EXPENSES
}

\author{
WOLFRAM F. RICHTER \\ CESIFO WORKING PAPER NO. 1311 \\ CATEgOry 1: Public FinAnCE \\ OCTOBER 2004
}

An electronic version of the paper may be downloaded

- from the SSRN website:

www.SSRN.com

- from the CESifo website:

www.CESifo.de 


\title{
EFFICIENCY EFFECTS OF TAX DEDUCTIONS FOR WORK-RELATED EXPENSES
}

\begin{abstract}
In this paper it is shown that allowing the deduction of work-related expenses has a strictly positive effect on tax efficiency only if two conditions hold jointly: (i) The expenses should be interpretable as real cost and (ii) the expenses should be required for increasing taxable income. Otherwise deductions are inefficient, neutral or ambiguous. Thus it is argued that the cost of commuting to work should not be deductible as commuting does not increase taxable income. The efficiency enhancing effect of deducting other expenses like educational ones or expenses for housework and child care is challenged on the grounds that these expenses are largely pecuniary costs.
\end{abstract}

JEL Code: H21, H24.

Keywords: income tax deductions, commuting, housework, child care, educational expenses, efficient taxation, production efficiency.

\author{
Wolfram F. Richter \\ University of Dortmund \\ Department of Economics \\ 44221 Dortmund \\ Germany \\ Wolfram.Richter@uni-dortmund.de
}

This is the revision of a very preliminary version that has been presented at the 60th Congress of the IIPF 2004 in Milan under the title "Efficient, Inefficient and Neutral Tax Deductions for Work-Related Expenses". The revision has benefited from valuable suggestions made by various participants, Stefan Homburg and two anonymous referees. 


\section{Introduction}

The principle seems to be so self evident that it is hardly ever questioned. The principle suggests that income should only be taxed to the extent that it exceeds the expenses incurred by earning the income. In other words, earnings-related expenses should be tax deductible. The principle is well founded when applied to business expenses. By deducting all costs of business activity from revenues net income obtained equals profit. A tax on pure profit is ideal in so far as it generates revenue without deadweight loss and as it is considered to serve the equity objective. The case is less clear, however, with work-related expenses. The disutility of labor not being deductible the question naturally arise why and which other costs should be deductible. This paper tries to shed light on this basic question of income taxation. And it does so in an optimal taxation framework.

The question of optimal deductibility strongly suggests itself when studying the practice of allowing the deduction of specific expenses. Even if consideration is restricted to the practice of single countries, peculiarities and inconsistencies are striking. Baldry (1998, p. 48) reports about Australia that expenses for education are deductible if they can lead to promotion and increased salary in the taxpayer's existing employment but that they are not deductible if they allow the taxpayer to enter a new and even a higher-paying occupation. He finds such practice arbitrary and contradictory and he mentions other provisions of similar dubiousness. ${ }^{2}$ Even greater peculiarities and inconsistencies can be identified in cross-country comparisons of

\footnotetext{
${ }^{2}$ According to Due (1977, p. 41-42) similar peculiarities are characteristic of U.S. tax law.
} 
taxation. The most striking example is the treatment of commuting expenses. For some countries they are considered to be deductible expenses while for others they are not (Wrede, 2001, p. 80). The United States and the United Kingdom are prominent examples treating traveling expenses to work as not deductible items. Other countries, notably Germany and the Scandinavian countries, allow taxpayers to deduct commuting expenses from earned income. Such opposing practice provokes the question of which rule is optimal in any well defined sense.

Although there exist interesting attempts to derive rigorous answers to this question the state of discussion is anything but satisfactory. This becomes apparent just by comparing the contributions of Baldry (1998) and Wrede (2001). The former concludes that "on balance, there is a strong case against employee tax-deductibility of wage-related expenses on both efficiency and equity grounds" whereas the latter derives the result that commuting expenses should be deductible by more than one hundred percent given certain assumptions concerning mobility and taxation. This striking contradiction less raises the question of who is right or wrong but more of when do wage-related expenses qualify for deductibility and when do they not? This paper aims at shedding light on this question. It is shown that allowing the deduction of work-related expenses has a strictly positive effect on tax efficiency only if two conditions hold jointly: (i) The expenses should be interpretable as real cost and (ii) the expenses should be required for increasing taxable income. As the latter is being disputed in the case of commuting this paper pleads for denying deduction. Even partial deductibion violates tax efficiency. Hence deductions for commuting are an example of inefficient ones. Deductible expenses should also be interpretable as real cost and not only as some pecuniary cost. Otherwise deductibility has either no effect 
on tax efficiency or an ambiguous one. In this paper it is argued that deductions for educational expenses or expenses for housework and child care provide examples for deductions the efficiency effect of which is either neutral or ambiguous.

Such results are apt to stir controversy. In the past, various prominent German economists have strongly defended the practice of allowing commuting expenses to be (partially) deducted form earned income (Krause-Junk, 1996; Sinn, 2003). Equally, there are prominent textbooks stressing the efficiency enhancing effect of allowing the deduction of dependent-care expenses (Stiglitz, 1986, p. 435). Below it is argued that Stiglitz fails to convince when the fact is acknowledged that dependent-care expenses are largely pecuniary costs.

The paper is organized as follows. Section 2 presents a scenario in which the efficiency enhancing effect of tax deductions for wage-related expenses is indisputable. Section 3 assumes that the expenses are not required to increase taxable income. Hence deductibility is shown to be inefficient even if granted only partially. ${ }^{3}$ Sections 4 to 7 analyze expenses that are pecuniary costs. It is shown that the efficiency effect of allowing deduction is either neutral (Sections 4, 6 and 7) or ambiguous (Section 5). Section 4 assumes occupational choice to be exogenous while it is endogenous in the following Sections 5 to 7. In Section 5 the taxpayer can engage in two parallel activities one of which requires the employment of a housekeeper. In Section 6 the taxpayer can choose between employing or becoming a housekeeper. In Section 7 it is shown that allowing deduction of tuition fees that compensate for pure labor cost do not affect tax efficiency if pure profit generated by educational choice does not accrue to the private sector. Section 8 summarizes. The paper does not go into 
informational issues. These have been the major focus of related recent literature. See Baldry (1998) and Baake et al. (2004) who raise the question of how to tax workrelated expenses when they serve both production and consumption and when the government is unable to monitor their use.

\section{Efficient deductions}

The paper's focus is on efficiency. Hence the model of a representative individual is adopted. The individual has to choose between two time consuming activities. One is ordinary labor, $L$, and the other one is some qualified service, $S$, for which there is separate demand in the market. Both activities cause disutility, $V(L+S)$, with positive and increasing increments, $V^{\prime}, V^{\prime}>0$, and both earn taxable income at wage rates which are denoted by $w_{L}$ and $w_{S}$, respectively. Other than labor the provision of services induces expenses, $c S$, which, for the pure sake of simplicity, shall be proportional in the service quantity. All sources of wage income are uniformly taxed at a proportional rate, $t$. Throughout the paper the tax rate is assumed to be positive, $t>0$. The question is to what extent expenses required for providing services should be deductible. Let $a$ denote the rate at which deductibility is allowed. $a=1$ stands for full deductibility and $0<a<1$ for partial deductibility.

Given this highly stylized model the individual will maximize

$$
(1-t)\left[w_{L} L+w_{S} S\right]-(1-a t) c S-V(L+S) \text { in } L, S .
$$

\footnotetext{
${ }^{3}$ Sections 2 and 3 draw on Richter (2004).
} 
Labor and services are demanded by an employer maximizing profit, $F(L, S, K)-w_{L} L-w_{S} S$. The production function, $F$, is assumed to have standard properties: constant returns to scale in all three factors, positive partial derivatives, $F_{i}$, negative second derivatives, $F_{i i}$, and non-negative cross derivatives, $F_{i j}$, $i, j=L, S, K . K$ is some hidden fixed factor generating pure profit. After substituting marginal products for market wage rates the first-order conditions of (1) are written as

$$
(1-t) F_{L}=V^{\prime}=(1-t) F_{S}-(1-a t) c
$$

A benevolent tax planner will maximize social surplus,

$$
F(L, S)-c S-V(L+S)
$$

in $L, S, t, a$ subject to the behavioral constraint (2) and the tax revenue constraint

$$
t\left[L F_{L}+S F_{S}-a c S\right]=\text { constant }
$$

As expenses $c S$ enter (3) they have to be interpreted as real cost. This contrasts with later sections in which pecuniary costs are modeled. The planner's optimization is easily solved by standard Lagrangean technique. See Appendix. One obtains the following elasticity rule as first-order condition:

Proposition 1: Efficient taxation requires to balance relative tax wedges according to the rule

$$
\frac{F_{S}-c-V^{\prime}}{F_{L}-V^{\prime}}=\frac{v V^{\prime}+\Pi_{S}}{v V^{\prime}+\Pi_{L}} .
$$


$v=(L+S) V^{\prime \prime} / V^{\prime} \quad$ is the elasticity of marginal disutility whereas $\Pi_{S}=\frac{d}{d S}\left[F-L F_{L}-S F_{S}\right]=K F_{K S}$, and $\Pi_{L}$ are the marginal increases of pure profit with respect to $S$ and $L$, respectively.

In order to interpret (5) start by looking at the special case when returns to scale are constant in $L$ and $S$. In this particular case of vanishing pure profit the RHS of (5) equals one and $F_{L}=F_{S}-c$ results from (5). Interpret $F_{L}=F_{S}-c$ as condition of production efficiency. It is the first-order condition obtained when maximizing net production, $F(L, S, K)-c S$, subject to $V^{\prime}(L+S)=$ constant $\Leftrightarrow L+S=$ constant. Note that production efficiency is compatible with the behavioral constraints (2) only if full deduction, $a=1$, is allowed.

Corollary 1: If returns to scale are constant in $L$ and $S$, efficient taxation requires full deduction, $a=1$, of the cost, $c S$, incurred by providing taxable services.

Things are less clear in the case of non-constant returns to scale. In this case the RHS of (5) can be smaller or even larger than one. It is larger if, and only if, pure profit more strongly increases with a marginal increase in $S$ than it would increase with a marginal increase in $L, \Pi_{S}>\Pi_{L}$. By (2), the LHS of (5) is larger than one if, and only if, less than full deductibility is granted, $a<1$. Putting pieces together yields 
Corollary 2: If pure profit more strongly reacts to $S$ than to $L$, it is efficient to grant partial deduction, $a<1$, only. Vice versa, the efficient degree of deduction exceeds one if $\Pi_{S}<\Pi_{L}$.

Proposition 1 and its Corollaries are best understood if related to the Production Efficiency Theorem of Diamond and Mirrlees (1971). According to this theorem it is first-best to tax pure profit and given that all pure profit is fully taxed away or does not exist it is second-best to ensure production efficiency. If pure profit exists that, by assumption, is not taxable, it may be third-best to violate production efficiency. In this case it is efficient to tax those factors more heavily than others that have the stronger positive effect on profit. The rationale is that taxation should not induce substitution effects that generate non-taxable pure profit. This insight also explains the result of Wrede (2000). In this paper partial deductibility is shown to be efficient in a model in which an activity, interpreted as commuting, generates non-taxable pure profit.

Corollary 2 allows one to trace back the question of efficient deductibion to the question of which factors of production have the stronger effect on non-taxable pure profit. If this question cannot be answered empirically, it may be good policy not to differentiate at all. This pragmatic approach to taxation suggests to postulate a value of one for the RHS of (5) and to secure production efficiency by granting full deductibion, $a=1$. 


\section{Inefficient deductions}

Keep the setup as introduced in Section 2 and replace $S$ by some activity $D$ which does not earn taxable income. Commuting provides an example in point. It consumes time, is no leisure activity and does not earn taxable wage income. The latter may not be obvious and therefore needs some discussion.

Traveling to work is clearly related to work in some descriptive sense. However, one cannot reasonably assume that in the absence of taxation employers would be willing to pay for commuting. It simply does not help to increase revenues. As a rule, employers should therefore have no demand for commuting. Now assume that the cost of commuting, $c D$, is proportional in travelling time $D$ which by way of normalizing units of measurement can be equally interpreted as distance. Like labor, commuting provides disutility, $V(L+D)$. Because of this disutility it would not be appropriate to call commuting expenses $c D$ "consumptive" and to contrast them with the "productive" expenses $c S$ caused by providing taxable services .

Commuting must generate gains however. Otherwise nobody would incur direct expenses and disutility. Let $H(D)$ denote the gain from commuting. One my think of private savings in the cost of housing. It is reasonable to assume such savings as work places tend to be agglomerated and as prices of housing decline with an increasing distance to agglomerations. Let $H^{\prime}>0>H^{\prime}$, and assume that the gains from commuting are not taxable. This is a key assumption. One could argue instead that the gains are taxed as most countries have a tax on housing property. However, in a Tiebout world perfect mobility of households induces local jurisdictions to use the property tax as an instrument to internalize the marginal cost of congestion induced by 
the consumption of non-excludable local public goods (Hoyt, 1991). Hence it is a reasonable modeling strategy to abstract from these costs of congestion and from any local tax on housing. On the other hand, the practice of various European countries equally suggests to let commuting expenses be deductible at some rate $a$ from the wage tax. It will be demonstrated below that any non-negativity of $a$ harms tax efficiency. To get the result look at the individual's problem of allocating non-leisure time to the competing uses $L$ and $D$ :

$$
\max \left\{(1-t) w_{L} L+H(D)-(1-a t) c D-V(L+D)\right\} \text { in } L, D .
$$

After substituting $F_{L}$ for $w_{L}$ the first-order conditions are written as

$$
(1-t) F_{L}=V^{\prime}=H^{\prime}-(1-a t) c .
$$

A benevolent tax planner will maximize social surplus,

$$
F(L)+H(D)-c D-V(L+D)
$$

in $L, D, t, a$ subject to the behavioral constraints (7) and the tax revenue constraint

$$
t\left[L F_{L}-a c D\right]=\text { constant. }
$$

It is straightforward to demonstrate that $a<0$ holds in the optimum. See Appendix.

Proposition 2: Allowing non-negative deductibility of commuting expenses $c D$ violates second-best efficiency of taxation.

For understanding this result it is best to start from a scenario with $a=0<t$. The firstorder conditions of the household maximization can then be written as 
$(1-t) F_{L}=V^{\prime}=H^{\prime}-c$. From the perspective of efficiency the level of labor is too low while the choice of commuting is optimal. When starting from this situation the marginal variation of $a$ does not affect the social surplus generated by commuting. Hence it increases tax efficiency if $a$ is marginally reduced below zero and if the generated revenue is used to reduce the wage tax $t$. The gain from such a tax reform is of first order while the cost is one of second order. That explains why $a<0$ must hold in the optimum. It is simply not efficient to tax the use of non-leisure time if it earns income and not to tax it if it saves costs on housing.

The result has to be related to the literature. There are well-known first-best arguments for taxing commuting. The most prominent ones rely on the objective to internalize the external costs of environmental damage and traffic jam. Whether fighting urban sprawl requires corrective interventions in transport markets is a more debatable subject. Brueckner (2003) argues against the need for correction. Wrede (2001) provides an argument for subsidization. However, one may argue that Wrede's result is biased by equity considerations. He compares households that only differ by the fact that some commute while others not. He then studies the policy of securing equal utility to both households. Given this institutional constraint it is obvious that there must be compensation for the leisure cost of commuting. If the income of both types of households is taxed at the same rate, subsidizing commuting expenses presents itself as a way of securing equal utility.

In contrast to this, Proposition 2 provides an indisputable efficiency argument for taxing commuting. There is no equal utility constraint and the analysis relies on a 
representative household. No reference is made to external effects of commuting. The result is one of optimal taxation in a second-best framework. ${ }^{4}$

\section{Neutral deductions}

Deductions can be neither efficient nor inefficient. They can be neutral in a secondbest sense of efficiency. In other words, their effect is limited to redistribution in favor of those individuals claiming these deductions. It is argued that expenses for housework in general and child-care expenses in particular provide typical examples. This needs to be explained.

Consider a skilled individual who can earn income in the market only if somebody else does the job at home. That means that the labor supply of the skilled individual $S$ must be matched by a housekeeper's labor supply $H$. Assume that skilled labor earns $w_{S}=F_{S}$ and causes disutility, $V(S)$, while the person doing housework, is paid $w_{H}$ and suffers disutility $V_{H}(H)$. In equilibrium $w_{H}$ has to adjust so that the demand for housework $S$ balances its supply $H$. Now assume that all wage income is taxed and that the expenses for housework are deductible at the rate $a$. Thus the skilled individual will solve

$$
\max \left\{\left[(1-t) w_{S}-(1-a t) w_{H}\right] S-V(S)\right\} \text { in } S
$$

while the housekeeper maximizes $(1-t) w_{H} H-V_{H}(H)$. Note that the only real cost of employing a housekeeper is $V_{H}(H)$ while $w_{H} S$ is a pecuniary cost. After equating $S$

\footnotetext{
${ }^{4}$ The relevance of Proposition 2 is not restricted to commuting. Another delicate application is provided by the German practice to allow professors to deduct expenses for a home office from wage income. It is not easy to make a strong case for the assumption that professors' productivity is enhanced if they are allowed to work at
} 
with $H$ and after substituting $F_{S}$ for $w_{S}$ and $V_{H}{ }^{\prime}$ for $(1-t) w_{H}$ the first-order condition to $(10)$ can be written as

$$
(1-t) F_{S}-\frac{1-a t}{1-t} V_{H}^{\prime}=V^{\prime}
$$

A benevolent tax planner will maximize social surplus,

$$
F(S)-V(S)-V_{H}(S)
$$

in $S, t, a$ subject to the behavioral constraint (11) and the tax revenue constraint,

$$
t S\left[F_{S}+\frac{1-a}{1-t} V_{H}^{\prime}\right]=\text { constant. }
$$

The term $t S \frac{1-a}{1-t} V_{H}^{\prime}$ in brackets is obtained when netting the tax $t w_{H} S$ paid by the employee with the subsidy $a t w_{H} S$ given to the employer. It is straightforward to demonstrate that $t$ and $a$ are jointly undetermined in the second-best optimum.

Proposition 3: Deducting expenses for housework from taxable income has no effect on second-best efficiency as these expenses are pecuniary costs only.

For understanding the result set $\tau \equiv t\left[1+\frac{1-a}{1-t} V_{H}{ }^{\prime} / F_{S}\right]=t\left[1+(1-a) w_{H} / w_{S}\right]$. Interpret $\tau$ as the effective tax rate on skilled labor supply. The tax planner's problem can be restated equivalently in terms of $\tau$ instead of $t, a$. The tax planner maximizes (12) in $\tau, S$ subject to 


$$
(1-\tau) F_{S}=V^{\prime}+V_{H}^{\prime}
$$

and $\tau S F_{S}=$ constant.

Note that there is no true scope for optimization as the necessary degree of freedom is lacking. Still, any combination of $t$ and $a$ that generates the same value of $\tau \equiv t\left[1+\frac{1-a}{1-t} V_{H}{ }^{\prime} / F_{S}\right]$, evaluated at the optimal value of $S=H$, is a solution to the original problem (11) - (13). Hence $t$ and $a$ are indeterminate in the optimum. The economic interpretation is straightforward. By assumption, skilled labor supply has to be matched by a housekeeper's service. Hence $\tau=t\left[1+(1-a) w_{H} / w_{S}\right]$ is the effective tax on skilled labor supply. If $a$ is increased and if this increase is compensated by an increase in $t$ so that $\tau$ keeps constant, there is no reason why the skilled taxpayer should change labor supply. With $S$ fixed the matching labor supply, $H$, of the housekeeper is fixed as well and independent of the nominal tax rate $t$. Any increase in $t$ induces a perfectly compensating increase in $w_{H}$.

As mentioned before Proposition 3 contrasts with conventional textbook wisdom. It is fairly standard to argue that tax deductions for child-care expenses enhance labormarket efficiency. Stiglitz (1986, p. 435) is just a prominent example. However, when looked at from a labor market perspective, child care is just a specific form of housework. Hence Proposition 3 allows one to challenge the efficiency enhancing effect of child-care expenses. If one still likes to make a case for deduction one has to search for other reasons. 
A strong argument is equity. In fact, taxing parents at a rate that effectively exceeds the rate applied to persons without dependent children is difficult to reconcile with the ability-to-pay principle. Note that by definition $\tau$ exceeds $t$ if child-care expenses are less than fully deductible, $a<1$. Setting $\tau>t$ clearly distorts consumption efficiency. The distutility of labor comes to differ between individuals with and without children. Equally, $V^{\prime}$ and $V_{H}^{\prime}$, need not be equated in the optimum. However, consumption efficiency is nothing that is required by second-best efficiency.

Proposition 3 assumes that the skilled individual cannot choose between employing a housekeeper or not. If some scope of choice is assumed to exist, the choice of $a$ raises some broader policy issues. First one has to acknowledge that a housekeeper will only be employed if this provides utility to the employer. If this is assumed to hold, tax policy has to take account of the effect that the choice of $a$ may have on the efficiency of consumption. Two further issues arise if there is unemployment in the labor market or if the development of children is considered to suffer from insufficient care. Allowing deductibility of $a w_{H} S$ is a way of coping with unemployment, particularly among unskilled labor. With regard to child care, deductibility is a way of internalizing the negative effect of insufficient care to children. However, allowing $a w_{H} S$ to be deductible is not the only means to cope with such problems and there will be more targeted policies. Deductibility is a policy instrument that deserves to be considered in this context but that presumably ensures third-best solutions only.

One might speculate that deduction of child-care expenses is needed to secure an efficient fertility choice. If the effective tax on labor supply $\tau$ increases as the result of childbearing, fertility incentives are clearly weakened. Still the question is whether 
allowing the deduction of child-care expenses is a way of enhancing second-best efficiency. The question is structurally related to asking for the efficiency effect that the deduction of expenses for housework has on occupational choice. Just as deduction seems to be needed to secure efficient fertility choices one might speculate that deduction is needed to secure efficient occupational choices. In the next two sections the efficiency enhancing effect of deduction on occupational choice will be called into question.

\section{Ambiguous deductions}

Keep the setup as introduced in Section 4 and allow the skilled individual to engage in two parallel activities $S$ and $L$. Just as before, the supply of $S$ requires the time matching employment of a housekeeper whereas the supply of ordinary labor $L$ does not do so. Let $w_{L}$ denote the wage rate paid to ordinary labor. In this setting the skilled taxpayer will solve

$$
\max \left\{\left[(1-t) w_{S}-(1-a t) w_{H}\right] S+(1-t) w_{L} L-V(S+L)\right\} \text { in } S, L \text {. }
$$

The decision problem (14) models a scenario in which an activity requiring the time matching service of a housekeeper is substituted by another activity which does not require a housekeeper. Such a scenario can be interpreted as a kind of occupational choice. The choice is a gradual one which allows the taxpayer to engage in two different activities simultaneously. In contrast to this, zero-one decisions are modeled in Section 6 below. The housekeeper is assumed to maximize $(1-t) w_{H} H-V_{H}(H)$ just 
as before. After equating $S$ with $H$ and after substituting $F_{S}, F_{L}$ for $w_{S}, w_{L}$ and $V_{H}{ }^{\prime}$ for $(1-t) w_{H}$ the first-order conditions of (14) can be written as

$$
\begin{aligned}
& (1-t) F_{S}-\frac{1-a t}{1-t} V_{H}{ }^{\prime}(S)=V^{\prime}(S+L), \\
& (1-t) F_{L}=V^{\prime}(S+L) .
\end{aligned}
$$

A benevolent tax planner will maximize social surplus,

$$
F-V(S+L)-V_{H}(S)
$$

in $S, L, t, a$ subject to the behavioral constraints (15), (16) and the tax revenue constraint,

$$
t S\left[F_{S}+\frac{1-a}{1-t} V_{H}^{\prime}\right]+t L F_{L}=\text { constant } .
$$

One easily derives the following result (see Appendix).

Proposition 4: Let the returns to scale of $F$ be constant in $L, S$. Efficient taxation requires to balance relative tax wedges according to the rule

$$
\frac{F_{S}-V_{H}{ }^{\prime}-V^{\prime}}{F_{L}-V^{\prime}}=1+\frac{S}{S+L} \frac{V_{H}^{\prime \prime}}{V^{\prime \prime}} \equiv \rho>1 .
$$

(19) has some strong and some weak policy implication. The strong one says that the effective tax wedge on skilled labor, $\tau F_{S}=F_{S}-V_{H}{ }^{\prime}-V^{\prime}$, should exceed the tax wedge on ordinary labor, $t F_{L}=F_{L}-V^{\prime}$. This is a strong implication as it does not rely on equity. It only relies on tax efficiency in a second-best framework. Clearly, one would 
like to know what (19) means for $\tau$ relative to $t$ or for the efficient choice of $a$. Unfortunately little can be said without making more specific assumptions. Hence (19) does not allow us to derive a definite result with respect to $a$. $\tau>t \Leftrightarrow a<1$ is just as compatible with (19) as is $\tau \leq t \Leftrightarrow a \geq 1$. It is in this sense that allowing deduction of $w_{H} S$ is said to have an ambiguous effect on tax efficiency. This is the weak part of Proposition 4. The reason for lacking ambiguity is that production and consumption efficiency are not separable in the present model variant. First-best efficiency requires instead the equality of $F_{S}-V_{H}{ }^{\prime}$ and $F_{L}$. This equality stresses the hybrid character of $V_{H}{ }^{\prime}$. For skilled labor it is a cost of production and for the housekeeping it is a cost of consumption. (19) implies that in the second-best optimum the net return to skilled labor, $F_{S}-V_{H}{ }^{\prime}$, should exceed the net return to ordinary labor, $F_{L}$. Equalizing marginal products of labor, $F_{S}=F_{L}$, would definitely be not efficient.

For later reference consider a policy regime in which skilled labor is not allowed to deduct any work-related expenses. In contrast, firms are allowed to deduct expenses incurred by their employees as cost of business. Assume furthermore that policy restricts the scope of deduction to some share $a$ of the employees' expenses $w_{H} S$. In such a regime firms would maximize $F-w_{L} L-\left(w_{S}+a w_{H}\right) S$ while skilled labor maximizes $(1-t)\left[w_{S} S+w_{L} L\right]-(1-a) w_{H} S-V(S+L)$. Given constant returns to scale the problem of choosing $a$ and $t$ efficiently turns out to be structurally equivalent to the earlier one. Hence in the optimum condition (19) has to hold again. This demonstrates that the ambiguous efficiency effect of allowing deduction of $w_{H} S$ is not removed by just denying deduction and by allowing firms to refund wage-related expenses. 
Corollary 3: Denying employees to deduct expenses $w_{H} S$ and allowing employers to deduct these expenses instead does not remove the ambiguous effect on tax efficiency.

\section{Deductibility and choice of occupation}

Stick to the model as introduced in Section 4 and extend it to allow for occupational choice as a zero-one decision. This requires the distribution of taxpayers working in different occupations to be endogenous. Let $N$ denote the number of housekeepers and $1-N$ the number of taxpayers employing a housekeeper. Market clearing requires

$$
N H=(1-N) S
$$

Occupational choice is in equilibrium if housekeepers yield the same level of utility as the taxpayers employing housekeepers,

$$
(1-t) w_{H} H-V_{H}(H)=\left[(1-t) F_{S}-(1-a t) w_{H}\right] S-V(S) .
$$

Consider the tax planner's problem. By maximizing the utility of one type of household the utility of the other type is maximized as well. Without loss of generality let us assume that the tax planner maximizes the utility of housekeepers, $(1-t) w_{H} H-V_{H}(H)$. The constraints are (20), (21), the first-order conditions to the left and right-hand sides of (21) and the tax revenue constraint,

$$
(1-N) t S\left[F_{S}-a w_{H}\right]+N t w_{H} H=\text { constant. }
$$

The control variables are $a, t, S, H, w_{H}, N$. It is shown in the Appendix that $t$ and $a$ are jointly undetermined in the second-best optimum. 
Proposition 5: Deducting expenses for housework from income continues to have no effect on second-best efficiency if occupational choice is endogenous.

The intuition is similar to the one given for Proposition 3. The labor supply and the utility of the taxpayer employing housekeeper services is fully determined by the effective tax rate $\tau \equiv t\left[1+\frac{1-a}{1-t} V_{H}^{\prime} / F_{S}\right]=t\left[1+(1-a) w_{H} / w_{S}\right]$. If $a$ is increased and if this increase is compensated by an increase in $t$ so that $\tau$ keeps constant, neither labor supply nor utility change. Because of (21) the utility of housekeepers does not change either. Hence $H$ must stay constant. The increase in $t$ is perfectly compensated by an increase in $w_{H}$. If $S, H$ are optimally chosen, any tax reform that keeps $\tau$ constant has no real effects.

\section{Deductibility and choice of schooling}

The model as set up in Section 4 is inappropriate to discuss educational expenses. One of the features that may give reason to objection is the following. If the model were to be given an educational interpretation, the housekeeper would have to be interpreted as a teacher. An unpleasant implication, though a minor one, were that one would have to abstract from the fact that teachers have to be educated, too. This may however be considered a necessary and acceptable modeling simplification. Definitely not acceptable is the implication that the same time $S$ is used by the educated taxpayer both for schooling and for providing skilled labor. Hence consider the following 
adaptation of Section 4's model. Let $S$ denote the time of schooling, $L$ the supply of labor and $V(S+L)$ the disutility derived from doing both. The teacher supplies $S$ according to $(1-t) w_{H}=V_{H}{ }^{\prime}(S)$. Schooling increases labor productivity, $w_{S}=f(S)$, with positive but decreasing marginal returns, $f^{\prime}>0>f^{\prime \prime}$. An immediate implication of decreasing returns is that schooling generates pure profit which even a wage tax does not fully tax away. Instead, pure profit from schooling after wage tax is given by $\pi=(1-t)\left[L f(S)-L f^{\prime}(S) S\right]>0$. Let us assume that this pure profit does not accrue to the educated taxpayer and that it is fully taxed away instead by a fictitious separate tax. The reason for making this assumption is a theoretical one. If there were some pure profit accruing to the private sector, optimal choices of $t$ and $a$ could no longer be considered to be second-best solutions. Furthermore, the present analysis is to identify the effect that deducting educational expenses has on efficiency. Hence any disturbing effect from other sources like positive private profits shall be suppressed. Given all this, a tax planner will maximize $L f(S)-V_{H}(S)-V(S+L)$ in $a, t, L$ and $S$ subject to the behavioral constraints,

$$
\begin{aligned}
& (1-t) L f^{\prime}(S)-\frac{1-a t}{1-t} V_{H}^{\prime}(S)=V^{\prime}(S+L), \\
& (1-t) f(S)=V^{\prime}(S+L),
\end{aligned}
$$

and the tax revenue constraint,

$$
(1-a) \frac{t}{1-t} S V_{H}{ }^{\prime}(S)+L f(S)-(1-t) L f^{\prime}(S) S=\text { constant. }
$$

The first term of (25) is obtained when netting the wage tax paid by the teacher with the loss of wage tax induced by deducting educational expenses. The second term is 
gross labor income and the third is labor income earned by the educated taxpayer net of taxes on wage income and on pure profit. One easily shows that $t$ and $a$ are jointly indeterminate in the optimum. The proof parallels the one of Proposition 5 and may therefore be skipped.

Proposition 6: If all pure profit from schooling is taxed away, deducting educational expenses that are pecuniary costs only has no effect on second-best efficiency.

Propositions 6 has to be related to the literature that analyzes the optimal taxation of human capital accumulation. However, a direct comparison of results is difficult for the following reason. The literature is largely one on third-best efficiency. The following two causes preventing second-best solutions are typically modeled. One is the assumption that pure profit accrues to the educated taxpayer. The other concerns the structure of income taxation in a multi-period framework. Thus it is typically assumed that cash-flow taxation of human capital is combined with accrual taxation of physical capital (Trostel, 1993; Nielsen and Sörensen, 1997; and Milesi-Firetti and Roubini, 1998; Bovenberg and Jacobs, 2003). Deducting educational expenses is hardly ever questioned in this context. Instead, the general consensus seems to be that all educational expenses should be treated like costs of capital investment which means that they should be granted deduction (Hope and Miller, 1988; Trostel, 1993; Nerlove et al., 1993; Judd, 1998). The fact that it may make a great difference whether educational expenses are real or pecuniary costs is only vaguely and non- 
systematically acknowledged (Milesi-Ferretti and Roubini, 1998). In contrast, the present analysis stresses the difference. Only the deduction of real cost is shown to be indisputably efficient. The deduction of the educators' wage bill has been shown to have no effect on second-best efficiency if only pure profit of schooling is taxed away. If pure profit is not taxed away, it may well be different. Still, intuition suggests that if deduction of educational expenses has a positive effect on schooling at all, this will increase pure profit from schooling which as such is harmful for tax efficiency. Hence it is fair to conclude that the overall efficiency effect of deducting educational expenses that are only pecuniary costs is ambiguous. As a result it is by no means clear whether tax deductibility of tuition fees can and should be recommended across the board. This result may help to rationalize the practice of many countries not to allow full deduction of educational expenses. Traditionally such a restrictive policy is justified by either equity concerns or by referring to the generous public subsidies given to the educational sector anyway.

\section{Summarizing and concluding remarks}

According to the various results derived in this paper allowing deduction of workrelated expenses has a strictly positive effect on tax efficiency only if two conditions hold jointly: (i) The expenses should be interpretable as real cost and (ii) the expenses should be required for increasing taxable income. Both conditions have been assumed to hold in Section 2 and it has been shown that full deduction is a necessary means to ensure production efficiency given that no pure profit accrues to the private sector. The necessity of condition (ii) is suggested by the analysis of commuting expenses in 
Section 3. There it has been argued that commuting is an example for expenses failing to increase taxable income. This is so as employers have no demand for commuting. It does not increase their revenues. If that is correct, commuting should even be taxed before it is granted tax deduction. Condition (i) is a more subtle one and it has been the subject of scrutiny in the remaining Sections 4 to 7 . The discussion starts in Section 4 from the observation that expenses for housework in general and for child care in particular are pecuniary costs. It has been shown that allowing deduction for such expenses has no real effect on tax efficiency. The deductions are perfectly neutral. In Sections 5 and 6 this result has been subjected to a test of robustness by allowing taxpayers to make occupational choices. If individuals can choose to become either a housekeeper or a skilled taxpayer employing a housekeeper, allowing deduction of expenses for housework continues to be neutral with respect to tax efficiency (Section 6). If individuals can simultaneously engage in two activities one of which requires housekeeping services while the other one does not do so, allowing deduction for housework has an ambiguous effect on tax efficiency (Section 5). That means that little can be said about the efficiency enhancing effect of granting deduction. All one can say is that skilled labor should optimally bear more tax than housework. As taxes paid are the product of tax rates and wage rates little of some generality can be said about the efficient differentiation of effective tax rates or - to state the same thing equivalently - about the efficient extent of deduction granted to housekeeping expenses. This is so, as in the underlying model production and consumption efficiency cannot be separated. For skilled labor the housekeeper's disutility of labor is a cost of production while for housekeeping it is a cost of consumption. Finally, Section 7 turned to an analysis of educational expenses. It has been shown that 
deducting pecuniary costs has no effect on second-best efficiency if only any disturbing effect of pure profit from schooling is suppressed. The latter requires, as suggested by the production efficiency theorem of Diamond and Mirrlees, that the pure profit from schooling does not accrue to the private sector. If it does, optimal taxation enters the realm of third best and the efficiency effect of deducting educational expenses that are pecuniary costs must be questioned.

If the deduction of wage-related expenses is indisputably efficient only in some rare cases, one might conclude that work-related expenses should best be not deductible at all. In fact, this is the conclusion drawn by Baldry (1998). It is corroborated by this paper's result that deductions are only efficient if the expenses are required to provide special services demanded by employers. Under such circumstances one should however expect employers to willingly carry the expenses by themselves. They have to pay for the full resource cost of service provision anyway. Hence, if the provision requires specific expenses, it should make no great difference whether employers or employees pay for them. According to Baldry, denying deductibility to employees would have the advantage of eliminating a particular source of inefficiency. This inefficiency is caused by the dual use of even those expenses that are required to increase taxable income. Typically, they can equally be used for non-occupational, private consumption and the government lacks the information to differentiate between the two uses. Denying employees the deduction of wage-related expenses would make it easier to tax the consumptive ones as required by a policy of tax-cut-cum-base broadening. 
Although Baldry's proposal has charm it is not without problems. When looked at more closely the proposal is not as convincing as it appears at first sight. There are three objections that deserve to be well taken. One is raised by collusive behavior of employees and employers. If the government is unable to differentiate productive and consumptive uses of expenses, little is gained by denying their deductibility to employees. Employers could offer to carry the expenses as part of a differentiated pay package. That would make the expenses tax deductible. Fringe benefits have to be assessed from this perspective. The second objection deserves even more thought. It might well conflict with efficient wage contracting if the employers are induced to pay for certain wage-related expenses. The cost of human capital investment is an example in point. The return to educational costs is not immediate. If the costs are carried by the employer, it has the effect of granting a loan to the employee. Employers are reluctant to grant loans to employees as it provokes moral-hazard behavior. Hence denying employees the deduction of educational costs might evoke an efficiency cost. This cost would have to be balanced against the benefit of not subsidizing consumptive expenses. This shows that the policy of allowing efficient tax deductions raises non-trivial questions once informational issues are taken seriously. Studying their effect on efficient taxation is beyond the scope of the present paper. ${ }^{5}$ This paper however allows one to criticize Baldry's proposal along a third line. The dual use of wage-related expenses is not the only problem which has to be addressed when allowing deduction. As has been stressed repeatedly, expenses should pass some tests if their deductibility is to be indisputably efficient. One stated test has been that the expenses are interpretable as real cost. The efficiency effect of deducting pecuniary

\footnotetext{
${ }^{5}$ For a first promising attempt see Baake et al. (2004).
} 
costs may well be ambiguous (Section 5). It then does not help just to deny employees to deduct wage-related expenses. Policy would have to lay down to what extent employers should be allowed to refund these wage-related expenses and to treat the refunds as cost of business. It has been shown by Corollary 3 that this policy problem is structurally equivalent to the one of fixing the extent by which employees are allowed to deduct wage-related expenses. Hence Baldry's proposal would not help to simplify the tax planner's problem.

\section{Appendix}

\section{Proof of Proposition 1:}

Let $\lambda, \sigma$ and $\gamma$ be the Lagrangean factors associated to $(1-t) F_{L}=V^{\prime}$, the second behavioral constraint in (2) and the tax revenue constraint (4), respectively. Partial differentiation with respect to $a$ yields $\sigma=\gamma S$ and differentiation with respect to $t$ yields $\lambda=\gamma L$. By differentiating with respect to $L$ and substituting $F_{L}-V^{\prime}$ for $t F_{L}$ one obtains

$$
\begin{aligned}
(1+\gamma)\left(F_{L}-V^{\prime}\right) & =\gamma\left[(L+S) V^{\prime \prime}-\left(L F_{L L}+S F_{S L}\right)\right] \\
& =\gamma\left[v V^{\prime}+\frac{d}{d L}\left(F-L F_{L}-S F_{S}\right)\right]=\gamma\left[v V^{\prime}+\Pi_{L}\right] .
\end{aligned}
$$

By symmetry, partial differentiation with respect to $S$ yields

$$
(1+\gamma)\left(F_{S}-c-V^{\prime}\right)=\gamma\left[v V^{\prime}+\Pi_{S}\right] .
$$

Dividing through proves Proposition 1.

The Proof of Proposition 2 follows along the same lines as the one of Proposition 1. By taking the partial derivatives with respect to $a, t, L$ one ends up with the condition

$$
(1+\gamma)\left(F_{L}-V^{\prime}\right)=\gamma\left[(L+S) V^{\prime \prime}-L F_{L L}\right]
$$


from which positivity of $\gamma /(1+\gamma)$ can be inferred. By differentiating with respect to $D$ and substituting -atc for $H^{\prime}-c-V^{\prime}$ one obtains

$$
\text { atc }=-\frac{\gamma}{1+\gamma}\left[(L+D) V^{\prime \prime}-D H^{\prime \prime}\right] .
$$

Proposition 2 follows after signing the right-hand side.

Proof of Proposition 4: Let $\sigma, \lambda$ and $\gamma$ be the Lagrangean factors associated to (15), (16) and (18), respectively. Partial differentiation with respect to $a$ yields $\sigma=\gamma S$ and differentiation with respect to $t$ yields $\lambda=\gamma L$. By differentiating with respect to $L$ and substituting $F_{L}-V^{\prime}$ for $t F_{L}$ one obtains

$$
(1+\gamma)\left(F_{L}-V^{\prime}\right)=\gamma(L+S) V^{\prime \prime} .
$$

Use has been made of constant returns to scale. By symmetry, partial differentiation with respect to $S$ yields

$$
(1+\gamma)\left(F_{S}-V_{H}{ }^{\prime}-V^{\prime}\right)=\gamma\left[(L+S) V^{\prime \prime}+S V_{H} "\right] .
$$

Dividing through proves Proposition 4.

Proof of Proposition 5: Maximize $H V_{H}{ }^{\prime}(H)-V_{H}(H)$ in a,t,S,H,N subject to (11), (20), (21), and (22) after substituting $(1-t) w_{H}$ by $V_{H}{ }^{\prime}(H)$. Let $\lambda, \mu$ and $\gamma$ be the Lagrangean factors associated to (11), (21) and (22), respectively. Partial differentiation with respect to $a$ yields $\lambda=[\mu+(1-N) \gamma]$. Making use of this equality and taking the partial derivative with respect to $t$ we end up with $\gamma[N H-(1-N) S]=0$. Because of $(20), t$ is indeterminate in the optimum. 


\section{References}

Baake, P., R. Borck and A. Loeffler, 2004, Complexity and progressivity in income tax design: Deductions for work-related expenses, International Tax and Public Finance 11, 299-312.

Baldry, J., 1998, Income tax deductions for work-related expenses: The rationale examined, Australian Economic Papers 37, 47-57.

Bovenberg, A.L. and B. Jacobs, 2001, Redistribution and education subsidies are Siamese twins, CentER Disc. Paper, 2001-82.

Brueckner, J.A., 2003, Transport subsidies, system choice, and urban sprawl, CESifo WP No. 1090.

Diamond, P. and J.A. Mirrlees, 1971, Optimal taxation and public production, I Production efficiency, II Tax rules, American Economic Review 61, 8-27 and 261278.

Due, J.F., 1977, Personal deductions, in: Comprehensive Income Taxation, J.A. Pechman, ed., The Brookings Institution, Washington, D.C., 37-74.

Hope, J. and P. Miller, 1988, Financing tertiary education: An examination of the issues, Australian Economic Review, 4th Quarter, 37-57.

Judd, K.L., 1998, Taxes, uncertainty, and human capital, American Economic Papers and Proceedings 88, 289-292.

Krause-Junk, G., 1996, Umstrittene Kilometerpauschale, Wirtschaftsdienst, 461-463.

Milesi-Ferretti, G.M. and N. Roubini, 1998, On the taxation of human and physical capital in models of endogenous growth, Journal of Public Economics 70, 237254.

Nerlove, M., A. Razin, E. Sadka and R.K. von Weizsäcker, 1993, Comprehensive income taxation, investment in human and physical capital, and productivity, Journal of Public Economics 50, 397-406.

Nielsen, S.B. and P.B. Sörensen, 1997, On the optimality of the Nordic system of dual Income taxation, Journal of Public Economics 63, 311-329.

Richter, W.F., 2004, Pendeln, Entfernungspauschale und allokative Effizienz der Einkommensbesteuerung, ifo Schnelldienst 57, 5, 5-8.

Sinn, H.W., 2003, Hände weg von der Entfernungspauschale! Süddeutsche Zeitung, $25^{\text {th }}$ Sept.

Stiglitz, J.E., 1986, Economics of the Public Sector, W.W. Norton, New York.

Trostel, P.A., 1993, The effect of taxation on human capital, Journal of Political Economy 101, 327-350.

Wrede, M., 2000, Tax deductibility of commuting expenses and leisure“, FinanzArchiv 57, 216-224.

Wrede, M., 2001, Should commuting expenses be tax deductible? A welfare analysis, Journal of Urban Economics 49, 80-99. 


\section{CESifo Working Paper Series}

(for full list see www.cesifo.de)

1249 Francesco Giavazzi and Guido Tabellini, Economic and Political Liberalizations, July 2004

1250 Yin-Wong Cheung and Jude Yuen, An Output Perspective on a Northeast Asia Currency Union, August 2004

1251 Ralf Elsas, Frank Heinemann, and Marcel Tyrell, Multiple but Asymmetric Bank Financing: The Case of Relationship Lending, August 2004

1252 Steinar Holden, Wage Formation under Low Inflation, August 2004

1253 Ngo Van Long and Gerhard Sorger, Insecure Property Rights and Growth: The Roles of Appropriation Costs, Wealth Effects, and Heterogeneity, August 2004

1254 Klaus Wälde and Pia Weiß, International Competition, Slim Firms and Wage Inequality, August 2004

1255 Jeremy S. S. Edwards and Alfons J. Weichenrieder, How Weak is the Weakest-Link Principle? On the Measurement of Firm Owners' Control Rights, August 2004

1256 Guido Tabellini, The Role of the State in Economic Development, August 2004

1257 François Larmande and Jean-Pierre Ponssard, EVA and the Controllability-congruence Trade-off: An Empirical Investigation, August 2004

1258 Vesa Kanniainen and Jenni Pääkkönen, Anonymous Money, Moral Sentiments and Welfare, August 2004

1259 Panu Poutvaara and Andreas Wagener, Why is the Public Sector More Labor-Intensive? A Distortionary Tax Argument, August 2004

1260 Lars P. Feld and Stefan Voigt, Making Judges Independent - Some Proposals Regarding the Judiciary, August 2004

1261 Joop Hartog, Hans van Ophem, and Simona Maria Bajdechi, How Risky is Investment in Human Capital?, August 2004

1262 Thomas Eichner and Rüdiger Pethig, Efficient Nonanthropocentric Nature Protection, August 2004

1263 David-Jan Jansen and Jakob de Haan, Look Who's Talking: ECB Communication during the First Years of EMU, August 2004

1264 David F. Bradford, The X Tax in the World Economy, August 2004 
1265 Hans-Werner Sinn, Migration, Social Standards and Replacement Incomes. How to Protect Low-income Workers in the Industrialized Countries against the Forces of Globalization and Market Integration, August 2004

1266 Wolfgang Leininger, Fending off one Means Fending off all: Evolutionary Stability in Submodular Games, August 2004

1267 Antoine Bommier and Bertrand Villeneuve, Risk Aversion and the Value of Risk to Life, September 2004

1268 Harrie A. A. Verbon and Lex Meijdam, Too Many Migrants, Too Few Services: A Model of Decision-making on Immigration and Integration with Cultural Distance, September 2004

1269 Thomas Eichner and Rüdiger Pethig, Economic Land Use, Ecosystem Services and Microfounded Species Dynamics, September 2004

1270 Federico Revelli, Performance Rating and Yardstick Competition in Social Service Provision, September 2004

1271 Gerhard O. Orosel and Klaus G. Zauner, Vertical Product Differentiation When Quality is Unobservable to Buyers, September 2004

1272 Christoph Böhringer, Stefan Boeters, and Michael Feil, Taxation and Unemployment: An Applied General Equilibrium Approach, September 2004

1273 Assaf Razin and Efraim Sadka, Welfare Migration: Is the Net Fiscal Burden a Good Measure of its Economics Impact on the Welfare of the Native-Born Population?, September 2004

1274 Tomer Blumkin and Volker Grossmann, Ideological Polarization, Sticky Information, and Policy Reforms, September 2004

1275 Katherine Baicker and Nora Gordon, The Effect of Mandated State Education Spending on Total Local Resources, September 2004

1276 Gabriel J. Felbermayr and Wilhelm Kohler, Exploring the Intensive and Extensive Margins of World Trade, September 2004

1277 John Burbidge, Katherine Cuff and John Leach, Capital Tax Competition with Heterogeneous Firms and Agglomeration Effects, September 2004

1278 Joern-Steffen Pischke, Labor Market Institutions, Wages and Investment, September 2004

1279 Josef Falkinger and Volker Grossmann, Institutions and Development: The Interaction between Trade Regime and Political System, September 2004

1280 Paolo Surico, Inflation Targeting and Nonlinear Policy Rules: The Case of Asymmetric Preferences, September 2004 
1281 Ayal Kimhi, Growth, Inequality and Labor Markets in LDCs: A Survey, September 2004

1282 Robert Dur and Amihai Glazer, Optimal Incentive Contracts for a Worker who Envies his Boss, September 2004

1283 Klaus Abberger, Nonparametric Regression and the Detection of Turning Points in the Ifo Business Climate, September 2004

1284 Werner Güth and Rupert Sausgruber, Tax Morale and Optimal Taxation, September 2004

1285 Luis H. R. Alvarez and Erkki Koskela, Does Risk Aversion Accelerate Optimal Forest Rotation under Uncertainty?, September 2004

1286 Giorgio Brunello and Maria De Paola, Market Failures and the Under-Provision of Training, September 2004

1287 Sanjeev Goyal, Marco van der Leij and José Luis Moraga-González, Economics: An Emerging Small World?, September 2004

1288 Sandro Maffei, Nikolai Raabe and Heinrich W. Ursprung, Political Repression and Child Labor: Theory and Empirical Evidence, September 2004

1289 Georg Götz and Klaus Gugler, Market Concentration and Product Variety under Spatial Competition: Evidence from Retail Gasoline, September 2004

1290 Jonathan Temple and Ludger Wößmann, Dualism and Cross-Country Growth Regressions, September 2004

1291 Ravi Kanbur, Jukka Pirttilä and Matti Tuomala, Non-Welfarist Optimal Taxation and Behavioral Public Economics, October 2004

1292 Maarten C. W. Janssen, José Luis Moraga-González and Matthijs R. Wildenbeest, Consumer Search and Oligopolistic Pricing: An Empirical Investigation, October 2004

1293 Kira Börner and Christa Hainz, The Political Economy of Corruption and the Role of Financial Institutions, October 2004

1294 Christoph A. Schaltegger and Lars P. Feld, Do Large Cabinets Favor Large Governments? Evidence from Swiss Sub-Federal Jurisdictions, October 2004

1295 Marc-Andreas Mündler, The Existence of Informationally Efficient Markets When Individuals Are Rational, October 2004

1296 Hendrik Jürges, Wolfram F. Richter and Kerstin Schneider, Teacher Quality and Incentives: Theoretical and Empirical Effects of Standards on Teacher Quality, October 2004 
1297 David S. Evans and Michael Salinger, An Empirical Analysis of Bundling and Tying: Over-the-Counter Pain Relief and Cold Medicines, October 2004

1298 Gershon Ben-Shakhar, Gary Bornstein, Astrid Hopfensitz and Frans van Winden, Reciprocity and Emotions: Arousal, Self-Reports, and Expectations, October 2004

1299 B. Zorina Khan and Kenneth L. Sokoloff, Institutions and Technological Innovation During Early Economic Growth: Evidence from the Great Inventors of the United States, 1790 - 1930, October 2004

1300 Piero Gottardi and Roberto Serrano, Market Power and Information Revelation in Dynamic Trading, October 2004

1301 Alan V. Deardorff, Who Makes the Rules of Globalization?, October 2004

1302 Sheilagh Ogilvie, The Use and Abuse of Trust: Social Capital and its Deployment by Early Modern Guilds, October 2004

1303 Mario Jametti and Thomas von Ungern-Sternberg, Disaster Insurance or a Disastrous Insurance - Natural Disaster Insurance in France, October 2004

1304 Pieter A. Gautier and José Luis Moraga-González, Strategic Wage Setting and Coordination Frictions with Multiple Applications, October 2004

1305 Julia Darby, Anton Muscatelli and Graeme Roy, Fiscal Federalism, Fiscal Consolidations and Cuts in Central Government Grants: Evidence from an Event Study, October 2004

1306 Michael Waldman, Antitrust Perspectives for Durable-Goods Markets, October 2004

1307 Josef Honerkamp, Stefan Moog and Bernd Raffelhüschen, Earlier or Later: A General Equilibrium Analysis of Bringing Forward an Already Announced Tax Reform, October 2004

1308 M. Hashem Pesaran, A Pair-Wise Approach to Testing for Output and Growth Convergence, October 2004

1309 John Bishop and Ferran Mane, Educational Reform and Disadvantaged Students: Are They Better Off or Worse Off?, October 2004

1310 Alfredo Schclarek, Consumption and Keynesian Fiscal Policy, October 2004

1311 Wolfram F. Richter, Efficiency Effects of Tax Deductions for Work-Related Expenses, October 2004 